\title{
Construction and Development - Field Hockey Specific Skills' Test
}

\author{
Lalit Mohan ${ }^{1}$, Syed Tariq Murtaza ${ }^{2}$, Ashish Kumar Katiyar ${ }^{3, *}$ \\ ${ }^{1}$ Madhya Pradesh Men’s Hockey Academy, Department of Sports, Youth Welfare, Bhopal (M.P), India \\ ${ }^{2}$ Department of Physical Education, A.M.U., Aligarh (U.P.), India \\ ${ }^{3}$ Department of Physical Education, C.S.J.M. University, Kanpur (U.P.), India
}

Received October 12, 2020; Revised December 24, 2020; Accepted January 20, 2021

\section{Cite This Paper in the following Citation Styles}

(a): [1] Lalit Mohan, Syed Tariq Murtaza, Ashish Kumar Katiyar, "Construction and Development- Field Hockey Specific Skills' Test," International Journal of Human Movement and Sports Sciences, Vol. 9, No. 1, pp. 1 - 10, 2021. DOI: 10.13189/saj.2021.090101.

(b): Lalit Mohan, Syed Tariq Murtaza, Ashish Kumar Katiyar (2021). Construction and Development- Field Hockey Specific Skills' Test. International Journal of Human Movement and Sports Sciences, 9(1), 1 - 10. DOI: 10.13189/saj.2021.090101.

Copyright $\odot 2021$ by authors, all rights reserved. Authors agree that this article remains permanently open access under the terms of the Creative Commons Attribution License 4.0 International License

\begin{abstract}
In this existing time, the approaches made in field hockey are highly appreciable. As the synthetic surface introduced, many drastic changes have taken place. The game got a new trend for assessing functional playing abilities, and performance-based specific skills of advanced field hockey players. Field hockey is a stick-based game; where stick-work with speed and accuracy is required for controlling the movement of the ball. A number of specific skill tests had already been developed and produced to test the functional abilities of players' stick-work with other developmental work as fielding, dribbling, driving, controlling, and shooting while moving the ball. However, no existing test fulfills the criteria of modern field hockey playing skills. In order to test the specific skills and evaluate the performance level of advanced hockey players; the authors designed and constructed a test with proper selection of specific skills, in which many other movements related to advance skills were combined with stick-work. Wherein major focus was laid upon the player's ability to control the force element when contacting the ball, manipulation of stick-work by combining wrist and hand movement with quickness to control the movement of the ball while running in speed and hitting the right target was the prime concern. The idea presented in this paper is the need of the day and, the test is known as the 'Veer- Lalit Field-Hockey Skills Test' which meaningfully analyses the overall performances of advanced hockey players.
\end{abstract}

Keywords Field-Hockey Skills Test, Hit, Push, Scoop, Dribble, Sweep/Slap Shot, Receiving the Moving Ball

\section{Introduction}

History of hockey is very old. The game has been played since the $2000 \mathrm{BC}$ by different names but in similar fashion; and from 2000 BC to 2020 this game saw many ups \& downs with numerous changes. Though the game of ball and sticks, has adopted many advanced form now called hockey. About 50 years ago hockey has been played on a grass field with wooden stick. But modern hockey is played with modern equipment and hybrid grounds.

There are many tests available in sports literature regarding field hockey proposed by many authors. Field hockey skill testing goes back to 1929 when Hartley developed an empirical skill test (based on observation/ experience only) for field hockey [1]. The statistically valid test was first established by Schmithals \& French [2], followed by many other researchers who developed and constructed Field Hockey tests; as like, Friedel (1956); Singh (1957); Strait (1960); Illner (1968); Perry (1969); Henry (1970); Chapman (1982); Clarke \& Clarke (1987); SAI (1992) [3-12].

Out of these, Schmithals \& French developed a field 
hockey test which still remains as the most comprehensive that provides a good demonstration of the process of test construction from the selection of test items to the development of regression (Prediction) equations by Bosco and Gustafson [13]. However, Friedal in 1956 recommended a single item field hockey test for high school girls based on high validity coefficient (0.87) between the Friedal Hockey Skill test and Schmithals \& French Ball Control Test. SAI Hockey Skill Test is about 23 years old.

At present the number of published tests of field hockey skill is limited in number and very little has been done scientifically to formulate tests that measure playing ability [14], developed by many authors; as like Mehrotra (1996); Dureha \& Mehrotra (2003); Kasiviswanathan (2010); and Kumar, \& Mehrotra (2017) [15-18].

Since the ages, field hockey is a multiple high intensity activity sport with a multidirectional nature [19]. In these two decades developments of hockey tests had not advanced at the global plane. Most of these tests are containing proficiency only in one or two skills.

Wherein the game of hockey \& its rules have been progressively changing as the technological development advances; playing surfaces, hockey sticks and skills were changed over that period, which increased number of physiological and technical demands made on field hockey players particularly at elite level [20]. By adopting these modification and changes, some countries are quite ahead of others and did brilliantly in specific skill testing as like Lemmink (2004); Spencer (2006); Sunderland (2006); and Tapsell (2020) [21-24].

It is clearly visible that the skills have changed significantly over the time and thus it is required to develop a modern hockey test which measures the modern field-hockey skills, and to test out the capacity and capability of players during this competitive era of game. There are extensive numbers of tests available; however, there is currently no existing test which fulfills the criteria of modern field hockey playing skills [25].

\subsection{Test Objective}

The present study aims to design and construct field hockey specific test based on practical application which can be administered easily and used regularly, to allow coaches and researchers to test and measure the modern field hockey skills.

This test consists of all the important changes by which we can measure the performance level, physiological capacity and concentration over task performed by the players too.

\subsection{Utility and Practical Applications of the Test}

Consistent performance testing of athletes is a vital component of elite sport [26]. In field hockey, after receiving the ball successfully dribbling is an automatic process to a large extent; elite player requires high-level of technical skills, being able to dribble and control the movement of ball without losing speed while running [19]. In this specific test many valid and reliable skills measures, unified with pure acceleration; which allows to field hockey coaches to make more informed decisions when assessing athletes' coordinative abilities during speed and acceleration, whereas in the same time evaluating technical proficiency create a more holistic understanding of each athlete's physical attributes and technical strengths and weaknesses to assess the impact of their training program; in addition with this considerable training time usually dedicated to technical development. And, to assess facets like concentration over task and ego orientation in order to develop the psychological training programs to enhance athletes' performance [27].

\section{Methodology}

In this section participants, equipment required, Layout and marking, administration of the test and scoring procedure by using different types of scoring sheets filled by the official and the nomenclature of the test has been given in the following subsection:

\subsection{Participants}

This test is constructed for the male and female both the players, age ranging in between 18 to 35 yrs.

\subsection{Equipment Required for Administration of the Test}

As per the requirement of the test following equipment are required i.e. Standard Hockey balls (eight to ten); Hockey field (half side); White Tape Strips (for Marking); Cones (five in number); Stop watch (three); Measuring tape (at least 50 meter); Pen, Pencil; Score Sheets.

\subsection{Layout \& Marking}

To administer the test marking is done on the half side of the hockey field with the following specification:

1. On the both ends of center line there shall be 4 balls placed from where side line meets i.e. 45.70 meter from the end line.

2. At the middle of 23 meter line a box of 2 by 3 meters marked which is called as receiving box and it shall be marked in such way that it lies toward center line touching the 23 meter line. Receiving box is divided in three equal parts measuring $1 \mathrm{x} 1$ meters each.

3. Three cones are placed in such a way that the first cone is 4 meter away from receiving box, second cone is 1 meter away from the first cone and third cone is 1 meter away from second cone in a straight line. 
4. Three shooting boxes of 2 by 1 meters shall be marked on the shooting circle in such a way that first box is at the middle of the shooting circle and the rest two are 5 meters away each at either side of the first box.

5. The dimension of the goal post is $2.13 \mathrm{~m} \times 3.65 \mathrm{~m}$ and the whole goal post shall be divided in five columns and each column possesses a target area where the ball hits and a score is awarded to the player in the following manners.
- 4 Point Area = (4 squares of $0.45 \mathrm{~m} \times 0.45 \mathrm{~m}$ on each corner of the goal post).

- 3 Point Area $=(2$ rectangles of $1.22 \mathrm{~m} \times 0.45 \mathrm{~m}$ on each side of pole).

- 2 Point Area $=(2$ rectangles of $2.13 \mathrm{~m} \times 0.92 \mathrm{~m}$ beside of $4 \& 3$ point area).

- 1 Point Area = (1 rectangle of $2.13 \mathrm{~m} \times 0.92 \mathrm{~m}$ in between of 2 point area).

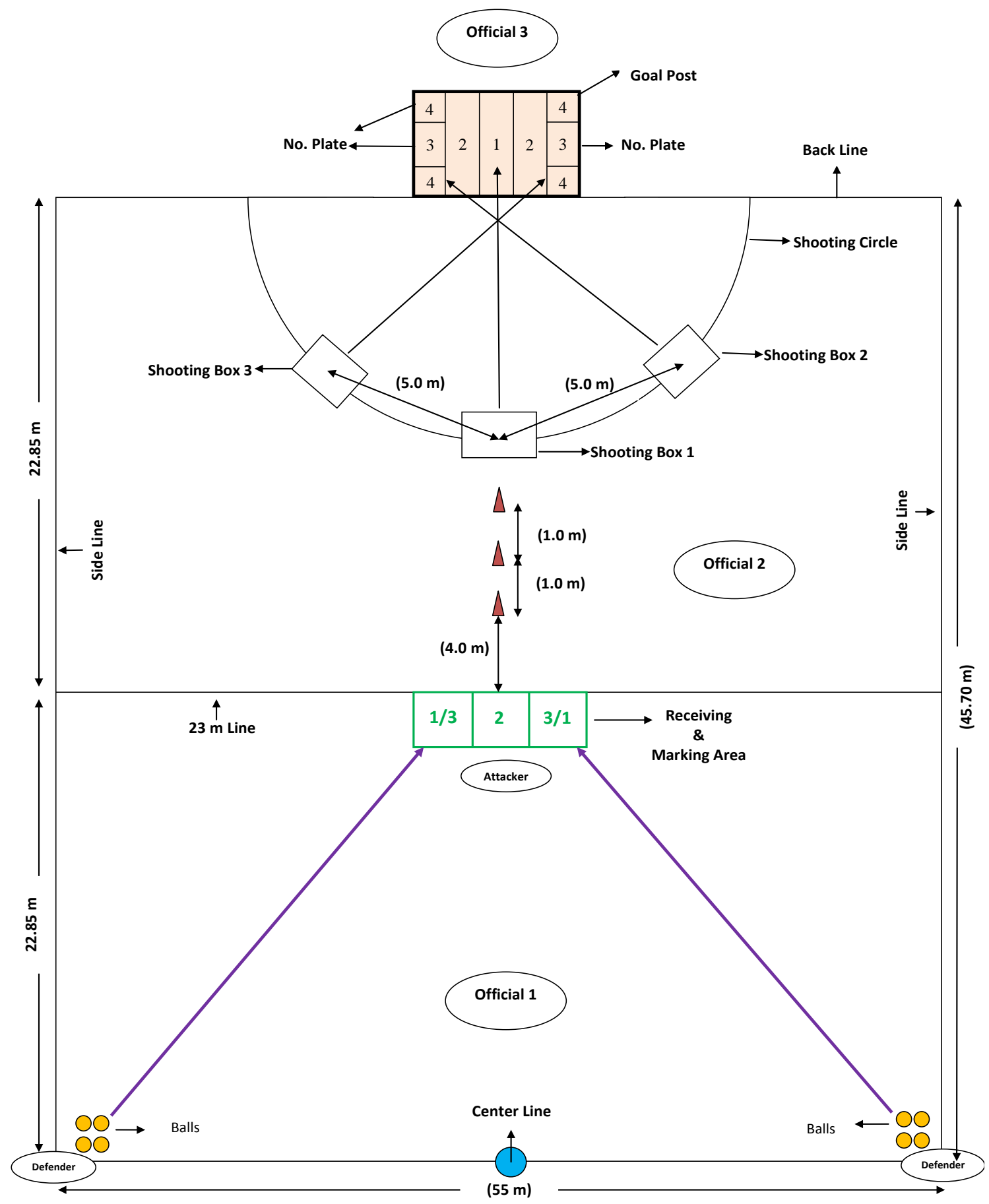

Figure 1. Layout and Marking of Hockey Field for Specific Skill Test 


\subsection{Test \& Its Administration}

This test consists of four basic skills; Hit, Push, Scoop, and Dribble, and six advanced skills; Right foot leading Scoop, Right foot leading Push, Sweep/Slap Shot, Low Back hand Hit, Right foot leading Hit, and Receiving the moving ball.

Before administering the test, the participants were given a demonstration of the test items by the test administrator or by any person having the knowledge of the execution of the test. Three trails would be helpful to get familiar with the test.

The test is conducted in groups, consisting of three members. Each player will act as a shooter as well as feeder, because after every eight (8) balls feeded by the feeders the players have to change their positions in a triangular way; wherein, the receiver comes in place of left side feeder and left side feeder shall go in place of right side feeder and right side feeder shall act as receiver.

1. The test starts with the feeder feeding the ball from right or left corner of the center line depending upon the choice of the receiver, that from which end he intends to receive the ball first.

2. Both feeders have four (4) balls each, the feeders have to feed the ball in alternate pattern i.e. one ball by right feeder and another by left feeder until their four balls are completed.

- The right feeder has to feed the ball by using the four ways i.e. (Hit, Scoop, Push, and Sweep/Slap shot).

- The left feeder has to feed the ball by using four ways i.e. (Hit, Right foot leading scoop, Right foot leading push, and Sweep/Slap shoot).

Note: The main aim of both the feeders is to score maximum points by feeding the ball in marked scoring/targeted area at the middle of 23 meter line.

3. The receiver has to receive each ball that is fed by the feeders with-in the receiving box or it goes outside of the receiving box. And if the receiver wants to increase his score then he has to drag the ball to the next highest point area in the receiving box and then he has to take the ball to the shooting boxes by following ways:

- First three balls by dribbling method.

- Second three balls by rolling method.

- Last two balls by using 3D Skill/ Popping up the ball over the cones.

4. As the player reaches near the shooting circle, he has to shoot the ball in the following ways:

- First two balls by Straight Hit from shooting box 1 .

- Second two balls by Right Foot leading Hit from shooting box 2 .

- Third two balls by times Low Back hand Hit from shooting box 3 .

- And the last two balls from any shooting box, performing any skill depending upon his choice.

\subsection{Scoring Procedure}

In this test the scoring would be done in two parts i.e. scoring for feeders and receivers and then after it would be merged to analyze for further utilities and to check their individual and group performances.

1. Scoring for the feeders: Feeders got the points according to their accuracy while feeding the ball to the receiver. The scores shall be awarded as for example the ball feeded by the feeder goes through the three (3) point area of receiving box three (3) points shall be awarded and so on. Zero (0) points shall be awarded if the ball moves outside the scoring area. The main difference in scoring between the right and left feeder is given below while scoring;

The score or point is awarded from the right side numbers shown in the receiving box i.e.

$$
\begin{array}{ll}
\text { - } & \text { For Right Side Feeder } \\
\text { - } & \text { For Left Side Feeder }
\end{array}
$$

\begin{tabular}{|l|l|l|}
\hline 3 & 2 & 1 \\
\hline 1 & 2 & 3 \\
\hline
\end{tabular}

Note: The sum of all four balls feeded in alternate pattern by the feeder shall be the total score.

2. Scoring for the Receiver: Scoring for receiver would be done in three parts and then it would further analyzed after complete scoring.

- Receiving within or outside of Box: Receiver is awarded points on the basis of his receiving ability; so he has to receive each ball that is feeded by the feeder within or outside the receiving box \& then drag to the highest point area in the receiving box. If the receiver receives the ball in two (2) point area of receiving box, two (2) points shall be awarded and so on. The receiver can increase the score by dragging the ball to the next high scoring box, for example, if the ball is received at one (1) point area, the receiver can drag it to three (3) point area to increase the score to three (3) point.

- Time taken to reach the shooting box: The receiver is also awarded points on the basis of time taken to reach the shooting box from the receiving box which are as follows:

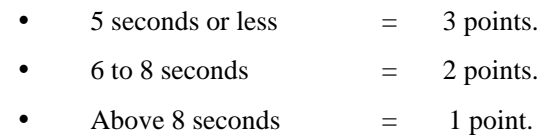

Note: The time keeper shall starts the time as he receives the ball or he touches the ball by his stick until he would not reach to the shooting box.

- Shooting ability from shooting boxes: The scores shall also be awarded on the basis of shooting ability, on reaching to the shooting boxes, the receiver has to shoot the ball in different ways from different shooting boxes and the scores shall be awarded as per the number plate on which the ball 
hits, for example if the ball hits two (2) point area, two points shall be awarded and so on.

Note: Higher score shall be taken if the ball strikes with the boundary line of two adjacent scores.

\subsection{Scoring Sheet}

Altogether (04) four types of scoring sheets were used in this test, in which (03) three scoring sheets are separately filled by the three different officials and a separate score sheet had also been used for accessing the overall performance of an individual player. All the (04) four score sheets are as given separately as per the following annexures.

- Scoring Sheet for Official 1 (Annexure 1).

- $\quad$ Scoring Sheet for Official 2 (Annexure 2).

- Scoring Sheet for Official 3 (Annexure 3).

- Combined Score Sheet (Annexure 4).

\subsection{Nomenclature of the Test}

Every test in the literature is christened as per the wish of the author(s); hence the test is named as 'Veer- Lalit Field-Hockey Skills Test'.

\section{Conclusions}

At present, the preceding test suggests the execution part only, which tests specific skills of field hockey players to determine differences in skill performance between players, rather than to monitor improvements or changes for a particular player. And, the validity and reliability of the constructed test would be tested separately. Here, in this paper authors' prime intention was to construct a comprehensive testing module with a limited number of test items with a greater level of dependability, which would be proved as a reliable, objective, and valid tool for testing the skills of good to elite field hockey male and female players age ranging from 18 to 35-year-olds. Analysis of the performance of players will be prepared later on, as per the individual scores by using the scoring table. And, the constructed test confirms the assessment of the skill of the modern era, administered on Astroturf with the latest equipment and rules.

\section{Recommendation}

The following areas could be strengthened in order to excel present and future challenges of hockey players.

- To ensure the objectivity, validity, and reliability of the constructed test, data needs to be collected for the formulation of test norms accordingly, based on gender differences, and for different age groups.

- The newly constructed skill test must cover the modern demands of the game, which must reflect the players' quality of being tested.

- Re-construction of old skill test as per modern playing surface.

- Priority must be given to test basic and modern skills.

\section{Conflicts of Interest}

There is no conflict of interest in between the author(s). 


\section{Annexure 1}

\section{Scoring Sheet for Official 1}

\section{Group No:-}

\begin{tabular}{|c|c|c|c|c|c|c|c|c|}
\hline Players Details & $\begin{array}{l}\text { Feeding the ball } \\
\text { from Right Side }\end{array}$ & Score & $\begin{array}{l}\text { Feeding the ball } \\
\text { from Left Side }\end{array}$ & Score & $\begin{array}{l}\text { Receiving } \\
\text { Ball from } \\
\text { Right Side }\end{array}$ & Score & $\begin{array}{l}\text { Receiving } \\
\text { Ball form } \\
\text { Left Side }\end{array}$ & Score \\
\hline Player 1 & Hit & & $\begin{array}{l}\text { Right foot leading } \\
\text { Hit }\end{array}$ & & Ball 1 & & Ball 1 & \\
\hline Name: & Scoop & & $\begin{array}{l}\text { Right foot leading } \\
\text { Scoop }\end{array}$ & & Ball 2 & & Ball 2 & \\
\hline \multirow[t]{2}{*}{ Chest No. } & Push & & $\begin{array}{l}\text { Right foot leading } \\
\text { Push }\end{array}$ & & Ball 3 & & Ball 3 & \\
\hline & Sweep/Slap Shot & & Sweep/Slap Shot & & Ball 4 & & Ball 4 & \\
\hline \multicolumn{9}{|c|}{ Total Score of Player 1} \\
\hline \multirow{2}{*}{ Player 2} & $\begin{array}{l}\text { Feeding the ball } \\
\text { from Right Side }\end{array}$ & Score & $\begin{array}{l}\text { Feeding the ball } \\
\text { from Left Side }\end{array}$ & Score & $\begin{array}{l}\text { Receiving } \\
\text { Ball from } \\
\text { Right Side }\end{array}$ & Score & $\begin{array}{l}\text { Receiving } \\
\text { Ball form } \\
\text { Left Side }\end{array}$ & Score \\
\hline & Hit & & $\begin{array}{l}\text { Right foot leading } \\
\text { Hit }\end{array}$ & & Ball 1 & & Ball 1 & \\
\hline Name: & Scoop & & $\begin{array}{l}\text { Right foot leading } \\
\text { Scoop }\end{array}$ & & Ball 2 & & Ball 2 & \\
\hline \multirow{2}{*}{ Chest No. } & Push & & $\begin{array}{l}\text { Right foot leading } \\
\text { Push }\end{array}$ & & Ball 3 & & Ball 3 & \\
\hline & Sweep/Slap Shot & & Sweep/Slap Shot & & Ball 4 & & Ball 4 & \\
\hline \multicolumn{9}{|c|}{ Total Score of Player 2} \\
\hline \multirow{5}{*}{ Player 3} & $\begin{array}{l}\text { Feeding the ball } \\
\text { from Right Side }\end{array}$ & Score & $\begin{array}{l}\text { Feeding the ball } \\
\text { from Left Side }\end{array}$ & Score & $\begin{array}{l}\text { Receiving } \\
\text { Ball from } \\
\text { Right Side }\end{array}$ & Score & $\begin{array}{l}\text { Receiving } \\
\text { Ball form } \\
\text { Left Side }\end{array}$ & Score \\
\hline & Hit & & $\begin{array}{l}\text { Right foot leading } \\
\text { Hit }\end{array}$ & & Ball 1 & & Ball 1 & \\
\hline & Scoop & & $\begin{array}{l}\text { Right foot leading } \\
\text { Scoop }\end{array}$ & & Ball 2 & & Ball 2 & \\
\hline & Push & & $\begin{array}{l}\text { Right foot leading } \\
\text { Push }\end{array}$ & & Ball 3 & & Ball 3 & \\
\hline & Sweep/Slap Shot & & Sweep/Slap Shot & & Ball 4 & & Ball 4 & \\
\hline \multicolumn{2}{|c|}{ Total Score of Player 3} & & & & & & & \\
\hline & & & & & & & Official & nature \\
\hline
\end{tabular}




\section{Annexure 2}

\section{Scoring Sheet for Official 2}

\section{Group No:-}

\begin{tabular}{|c|c|c|c|c|c|}
\hline Players Details & & Skill & Ball No. & Time in Sec & Score \\
\hline \multirow{4}{*}{ Player 1} & \multirow{10}{*}{$\begin{array}{l}\text { Time taken to carry the ball } \\
\text { from } 23 \text { meter line to } \\
\text { Shooting Circle }\end{array}$} & \multirow{3}{*}{ Dribbling } & Ball 1 & & \\
\hline & & & Ball 2 & & \\
\hline & & & Ball 3 & & \\
\hline & & \multirow{4}{*}{ Rolling } & & & \\
\hline \multirow{2}{*}{ Name: } & & & Ball 1 & & \\
\hline & & & Ball 2 & & \\
\hline \multirow{4}{*}{ Chest No. } & & & Ball 3 & & \\
\hline & & & & & \\
\hline & & 3D Skill/ & Ball 1 & & \\
\hline & & Popping Up the Ball & Ball 2 & & \\
\hline \multicolumn{5}{|c|}{ Total Score of Player 1} & \\
\hline \multirow{4}{*}{ Player 2} & \multirow{10}{*}{$\begin{array}{l}\text { Time taken to carry the ball } \\
\text { from } 23 \text { meter line to } \\
\text { Shooting Circle }\end{array}$} & \multirow{3}{*}{ Dribbling } & Ball 1 & & \\
\hline & & & Ball 2 & & \\
\hline & & & Ball 3 & & \\
\hline & & & & & \\
\hline \multirow{6}{*}{ Chest No. } & & \multirow{3}{*}{ Rolling } & Ball 1 & & \\
\hline & & & Ball 2 & & \\
\hline & & & Ball 3 & & \\
\hline & & & & & \\
\hline & & \multirow{2}{*}{$\begin{array}{l}\text { 3D Skill/ } \\
\text { Popping Up the Ball }\end{array}$} & Ball 1 & & \\
\hline & & & Ball 2 & & \\
\hline & & & Tota & re of Player 2 & \\
\hline \multirow{7}{*}{ Player 3} & \multirow{10}{*}{$\begin{array}{l}\text { Time taken to carry the ball } \\
\text { from } 23 \text { meter line to } \\
\text { Shooting Circle }\end{array}$} & & Ball 1 & & \\
\hline & & Dribbling & Ball 2 & & \\
\hline & & & Ball 3 & & \\
\hline & & & & & \\
\hline & & & Ball 1 & & \\
\hline & & Rolling & Ball 2 & & \\
\hline & & & Ball 3 & & \\
\hline \multirow{3}{*}{ Chest No. } & & & & & \\
\hline & & 3D Skill/ & Ball 1 & & \\
\hline & & Popping Up the Ball & Ball 2 & & \\
\hline \multicolumn{5}{|c|}{ Total Score of Player 3} & \\
\hline
\end{tabular}




\section{Annexure 3}

\section{Scoring Sheet for Official 3}

Group No:-

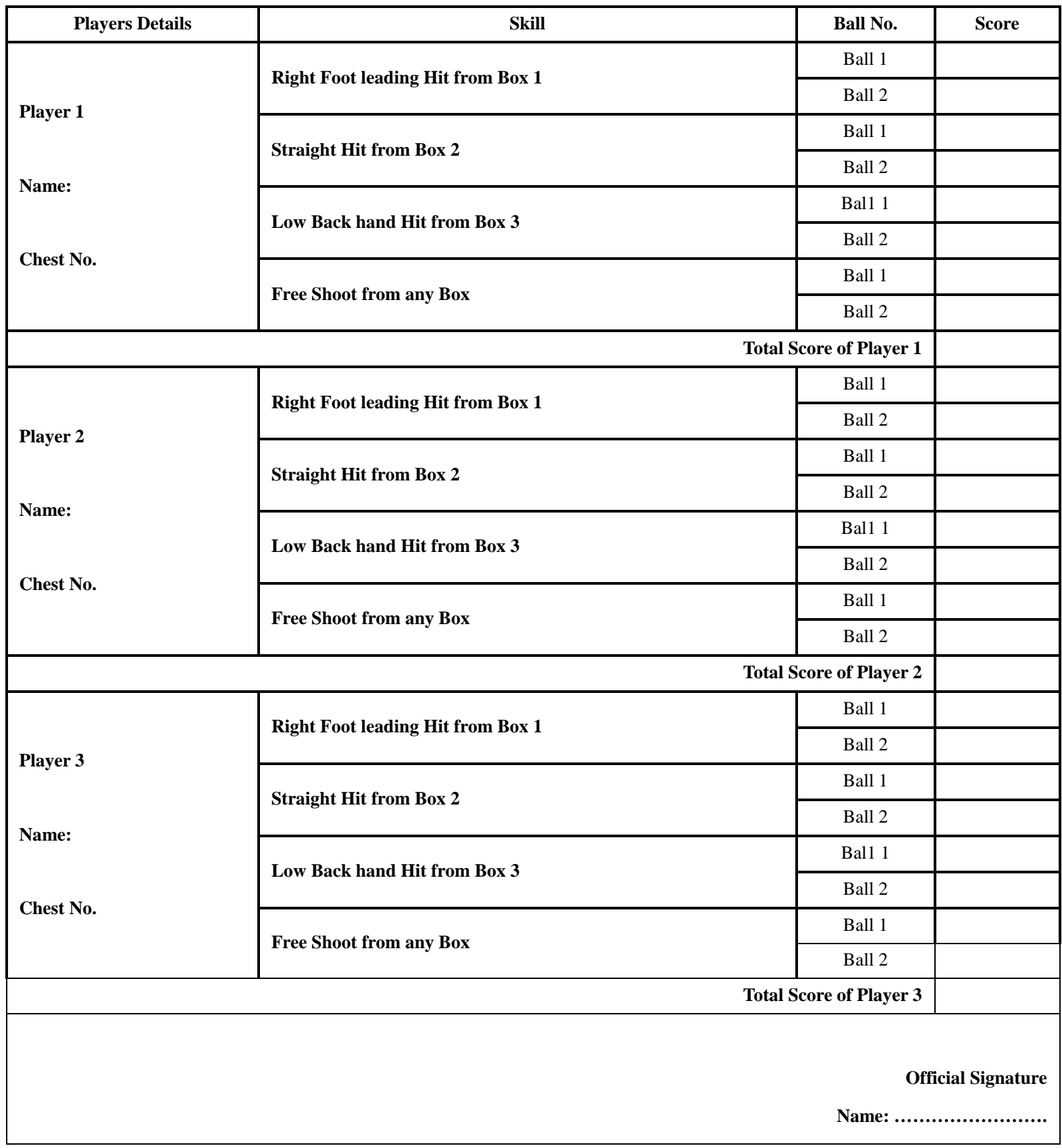




\section{Annexure 4}

'VEER- LALIT FIELD-HOCKEY SKILLS TEST'

(Combine Score Sheet)

\begin{tabular}{|c|c|}
\hline 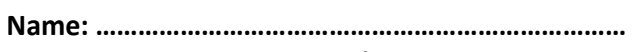 & Level of Play: State/ National/International (Tick) \\
\hline DOB : & \\
\hline 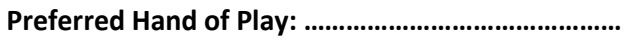 & Weather Condition \\
\hline Preferred Playing Position: ........................................... & $\begin{array}{l}\text { Test Session: Morning / Noon / Evening / Night (Tick) } \\
\text { Plaving Surface: Natural / Artificial (Tick) }\end{array}$ \\
\hline
\end{tabular}

\begin{tabular}{|c|c|c|c|}
\hline \multicolumn{2}{|c|}{ Feeding the ball from Right Side } & \multicolumn{2}{|c|}{ Feeding the ball from Left Side } \\
\hline Skill to be performed & Score Awarded & Skill to be performed & Score Awarded \\
\hline Hit & & Right foot leading Hit & \\
\hline Scoop & & Right foot leading Scoop & \\
\hline Push & & Right foot leading Push & \\
\hline Sweep/Slap Shot & & Sweep/Slap Shot & \\
\hline Total Score & & $\begin{array}{r}\text { Total Score } \\
\end{array}$ & \\
\hline
\end{tabular}

\begin{tabular}{|c|c|c|}
\hline Receiving Ball from Right Side & \multicolumn{2}{|c|}{ Receiving Ball form Left Side } \\
\hline Ball 1 & Ball 1 & \\
\hline Ball 2 & Ball 2 & \\
\hline Ball 3 & Ball 3 & \\
\hline Ball 4 & Ball 4 & \\
\hline Total Score & Total Score & \\
\hline
\end{tabular}

\begin{tabular}{|l|c|l|l|}
\hline Skill 3: Time taken to carry the ball from 23 meter line to Shooting Circle \\
\hline \multirow{3}{*}{ Dribbling } & Attempt No. & Time & Score Awarded \\
\hline \hline \multirow{3}{*}{ Rolling } & Ball 1 & & \\
& Ball 2 & & \\
\hline & Ball 3 & & \\
\hline \hline \multirow{2}{*}{ 3D Skill / Popping Up the Ball } & Ball 1 & & \\
\hline & Ball 2 & & \\
\hline & Ball 3 & & \\
\hline & Ball 1 & & \\
\hline & Ball 2 & & \\
\hline
\end{tabular}

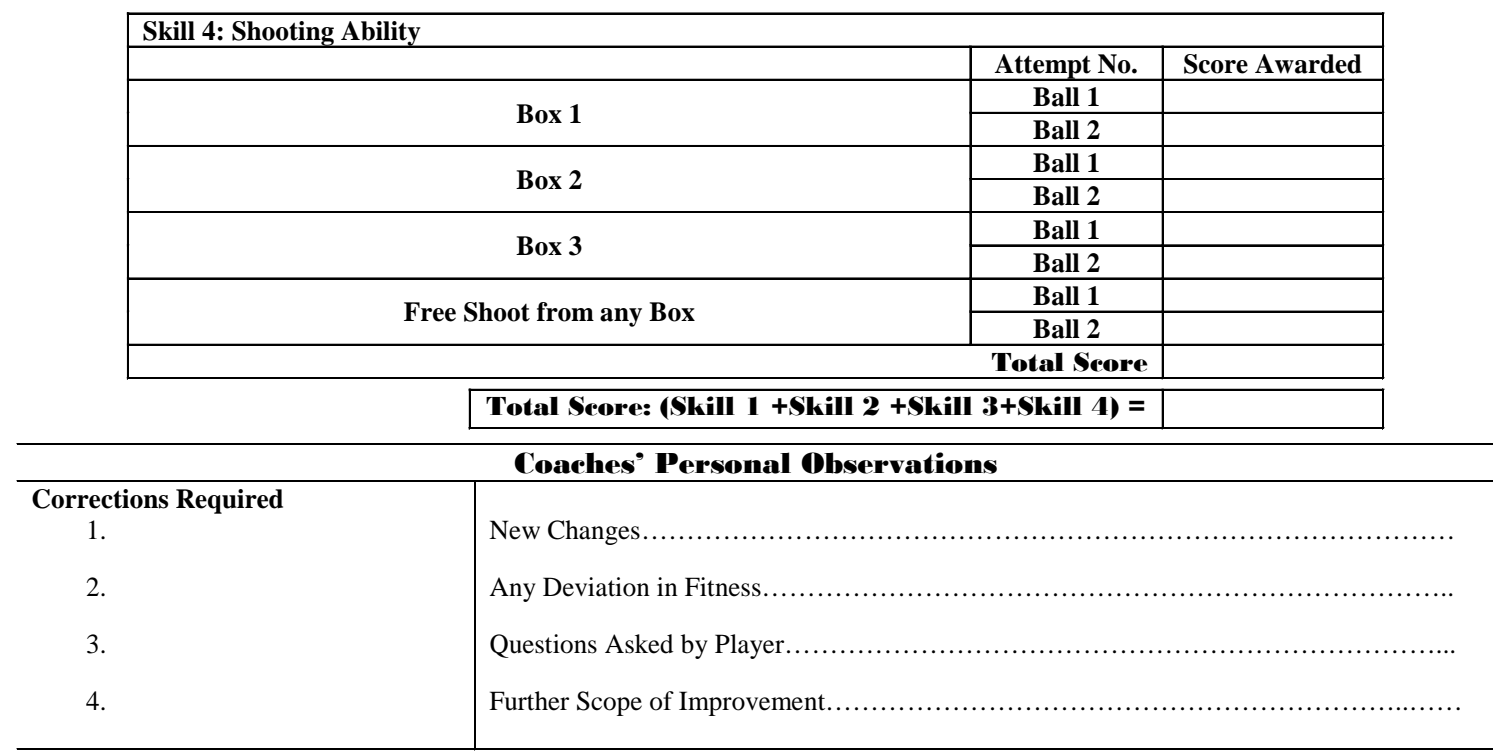




\section{REFERENCES}

[1] Thompson, EAC, "Rule 10: Penalty Bully," Malayan Saturday Post. pp. 21-22, 1929.

[2] Schmithals $M$ and E. French, "Achievement test is field hockey for college women,” Research Quarterly for Exercise and Sport; No. 11, pp.84-92, 1940.

[3] Friedel, J.E, “The development of a field hockey skill test for high school girls,” Master's Thesis, Illinois State Normal University, USA, 1956.

[4] Singh, Harbans, "Development of Tests in Field Hockey for Men": A Thesis Submitted to the Faculty of George Williams College in Candidacy for the Degree of Master of Science in Physical Education. George Williams College, 1957.

[5] Singh, Harbans, "Teaching Hockey Through Testing”, Ludhiana: The Indian Students Publishers, 1959.

[6] Strait, C.J, "The construction and evaluation of a field Hockey Skill test,” Master's Thesis, Smith College USA, 1960.

[7] Illner, J.A, "The construction and validation of a skill test for the drive in Field Hockey," Master's thesis, Southern Illionas University, USA, 1968.

[8] Perry, E.L, “An Investigation of field hockey skill test for college women," Unpublished Master's Thesis, Pennsylvavania State University, USA, 1969.

[9] Henry, M.E, "The validation of a test on Field Hockey," Unpublished Master's Thesis, Temple University, USA, 1970.

[10] Chapman NL, "Chapman ball control test - Field Hockey," Research Quarterly for Exercise and Sport; No. 53: pp. 239-242, 1982.

[11] Clarke, H. H., and D. H. Clarke, "Application of measurement to Physical Education,” Prentice-Hall Englewood Cliffs, New Jersey, U.S.A 1987.

[12] SAI, "National sports Talent Contest Schemes: Spotting \&Nurturing Sports Talent,” Sports Authority of India, New Delhi, 1992.

[13] Bosco, J.S and W.F. Gustafson, "Measurement and Evaluation in Physical Education, Fitness in Sports," Prentice Hall , INC., Eaglewood Cliff, New Jersey, USA, 1983.

[14] Wessel JA, Koening FB, "Field hockey". In:. Larson LA, (ed). Encyclopaedia of Sports Sciences and Medicine.
London: Collier-MacMillan, 679-680, 1971.

[15] Mehrotra Akhil, "Construction of Objective Skill Test Battery for Hockey Players,” Unpublished thesis, B.H.U., Varansi, 1996.

[16] Dureha DK, Mehrotra Akhil, "Teaching and Coaching Hockey,” (Janvani Prakashan (p) Ltd., Delhi), 2003.

[17] Kasiviswanathan R, "Construction of Hockey Skill Tests Battery for Tamilnadu School Boys of 14 to 16 Years,”. Unpublished Ph.D. Thesis, Manonmaniam Sundaranar University, 2010.

[18] Kumar, S. Suresh and Mehrotra Akhil, "Construction of skill based test item for measuring slap ability in field hockey", International journal of physical education, sports and health Vol 4, pp 21-23, 2017.

[19] Reilly T, Bretherton S., "Multivariate analysis of fitness of female field hockey players". In: Day JAP, ed. Perspectives in kinanthropometry. Champaign, IL: Human Kinetics:13542, 1986.

[20] Boyle PM, Mahoney CA, Wallace WFM, “The competitive demands of elite male field hockey”. J Sports Med Phys Fitness; 34:235-41. 1994.

[21] Lemmink K, Elferink-Gemser M, Visscher C. Evaluation of the reliability of two field hockey specific sprint and dribble tests in young field hockey players. Br J Sports Med 38: 138-142, 2004.

[22] Spencer M, Fitzsimons M, Dawson B, Bishop D, Goodman C. "Reliability of a repeated-sprint test for field-hockey," Journal of science and medicine in sport vol. 9,1-2, pp 181-4, 2006.

[23] Sunderland C, Cooke K, Milne H, Nevill ME. The reliability and validity of a field hockey skill test. Int J Sports Med 27: 395-400, 2006.

[24] L. C. Tapsell, M. J. Binnie, B. S. Lay, B. T. Dawson, and P. S. R. Goods, "Validity and Reliability of a Field Hockey-Specific Dribbling Speed Test,” J. strength Cond. Res., Aug. 2020.

[25] Keogh JWL, Weber CL, Dalton CT. Evaluation of anthropometric, physiological, and skill-related tests for talent identification in female field hockey. Can J Appl Physiol Rev Can Physiol Appl 28: 397-409, 2003.

[26] Tanner RK, Gore CJ; Australian Institute of Sport. Physiological Tests for Elite Athletes. 2013.

[27] Perera HPN, Jusoh M, Azam SMF, Sudasinghe SRSN, "Influence of Goal Orientation on Players' Performance with Special Reference to Sri Lanka National Team Sports," International Journal of Human Movement and Sports Sciences, Vol. 7, No. 4, pp. 89 - 97, 2019. DOI: 10.13189/saj.2019.070404. 